\title{
Collaborative Learning: Group Interaction in an Intelligent Mobile-Assisted Multiple Language Learning System
}

\author{
Christos TROUSSAS, Maria VIRVOU, Efthimios ALEPIS \\ Department of Informatics, University of Piraeus \\ 80 Karaoli and Dimitriou St., 18534, Piraeus, Greece \\ e-mail: \{ctrouss, mvirvou, talepis\}@unipi.gr
}

Received: July 2013

\begin{abstract}
This paper proposes a student-oriented approach tailored to effective collaboration between students using mobile phones for language learning within the life cycle of an intelligent tutoring system. For this reason, in this research, a prototype mobile application has been developed for multiple language learning that incorporates intelligence in its modeling and diagnostic components. One of the primary aims of this research is the construction of student models which promote the misconception diagnosis. Furthermore, they are the key for collaboration, given that students can cooperate with their peers, discuss complex problems from various perspectives and use knowledge to answer questions and/or to solve problems. Summarizing, in this paper, a mobile tutoring framework, built up in the context of student collaboration, is presented. Collaborative student groups are created with respect to the corresponding user models. Finally, the prototype was evaluated and the results confirmed the usefulness of collaborative learning.
\end{abstract}

Keywords: collaborative learning, error diagnosis, group interaction, intelligent tutoring systems, mobile-assisted collaborative learning, mobile learning, user modeling.

\section{Introduction}

In the past few years, there has been an increasing focus on mobile software applications as a result of the rapid development of mobile networks. The current wide spread of mobile devices and wireless technologies bring an enormous potential to e-learning, in terms of ubiquity, pervasiveness, personalization and flexibility (Caballe et al., 2010). Hence, people may seize the opportunity of sharing informational resources. The advent of the mobile technology era has provided us with a wide range of easily accessible resources on many subjects. This information sharing has provoked major transformations in our everyday life in the way we communicate, retrieve and share information, cooperate and socialize each other. Socialization has important pedagogical implications in mobile collaborative learning by seeing mobile devices as mediated tools for 
collaboration that support the learners' personal relationships and social interaction with their classmates (Caballe et al., 2010). Given that mobile devices can easily communicate with other devices of similar technology, they offer the possibility to learners of sharing files, data or simple messages. Learners can also cooperate with their peers or teachers, by being connected to a shared data network, further enhancing opportunities for communication. Furthermore, mobile devices are especially well suited to different environments simply because they are available in different contexts, and so can draw on those contexts to enhance the learning activity. Context-aware mobile devices can support students by allowing a learner to maintain their attention on the word and by offering appropriate assistance when required (Caballe et al., 2010). Mobile ComputerSupported Collaborative Learning (MCSCL) bases the success of current and future collaborative learning applications on the capability of such applications to incorporate mobility to support the collaborative learning process. In fact, there are many collaborative learning techniques (Iowa State University, 2009), such as the following: "Group discussion", "Assigned discussion leader", "Clusters", "Buzz groups", "Group survey", "Turn to your partner and...", "Think/Pair/Share", "Write/Pair/Share", "Note-taking pairs", "Jigsaw", "Individual presenation", "Round Robin”, "Critical debates", “Threestep interview", "Learning cell" and "Fish bowl".

Globalization is a phenomenon responsible for joining different cultures from all over the world, and therefore learning foreign languages has been accentuated by the emerging needs of modern life (Virvou and Troussas, 2011). The incorporation of mobile facilities in learning tools offers the quite important facility of time and place independence for the users who are going to use them (Virvou et al., 2011). Furthermore, collaborative learning combines both lines of thinking in order to improve learning and instruction in various areas of education (Dillenbourg and Fscher, 2007).

In view of the above, we have implemented a prototype mobile-assisted language learning system with collaborative support. Our system aims at providing a ubiquitous and collaborative environment for tutoring multiple languages, namely English anf French. In this paper, the authors tried to ameliorate the educational process by providing personalized instruction to students, since the system is designed to recognize the model of each learner, the learning material and the way of learning. Furthermore, the incorporation of the idea of encouraging students to learn in groups has become increasingly emphasized. The prototype also provides adaptivity, which is achieved by the incorporation of the student modeling component. The student modeling component involves the construction of a qualitative representation which accounts for student behavior in terms of existing background knowledge about the language learning domain. Our system also offers intelligence in its diagnostic component by providing error proneness to students' language errors. The communication between the system and its potential users as students is accomplished through the use of web services (Chen, 2002).

The remainder of this paper is organized as follows. In the next section, the related work and theoretical background about collaborative learning are presented. Following, we present a general overview of our system along with the methodologies used. In Section 4, we present some experimental results concerning our system. Finally, we conclude with the conclusions and future work in Section 5. 


\section{Related Work}

Collaborative learning is a quite significant issue in educational software. In all aspects of Intelligent Tutoring Systems (ITSs), collaborative support plays an important role. In this section, we try to imprint the speckle of the scientific progress in computer supported collaborative learning in terms of mobile-assisted language learning.

In (Sandberg et al., 2011), the authors conducted a study, in which three groups participated on the added value of mobile technology for learning English as a second language for primary school students. The first group had classroom lessons in English about zoo animals and their characteristics. The second group took classroom lessons and worked with a mobile application on location in a public zoo. The third group received the same treatment as the second but, as an extension, was allowed to take the mobile application home for a fortnight. A pre- and a post-test were conducted to measure the individual change in mastery of a set of targeted English words. The results showed that the group which took the mobile phone home improved the most. However, when the additional learning time, spent apart from school, of this third group was controlled for, the superior performance of the group disappeared. The results indicate that students are motivated to use the application in their spare time and that this benefits their learning. The conclusion is that formal school learning can be augmented by learning in an informal context, away from school.

In (Chang et al., 2011), the authors introduced mobile devices into an intensive reading course and allowed functions that are usually found only in the language laboratory to be easily and flexibly utilized in the general classroom. To enhance and improve the reading comprehension of English as a foreign language (EFL) reader, a computer-assisted-language-learning (CALL) system for use on PDAs, integrating an instant translation mode, an instant translation annotation mode, and an instant multi-users shared translation annotation function was developed to support a synchronously intensive reading course in the normal classroom. Experiments were conducted to analyze the usage of the system, including the attitude and satisfaction of users.

In (Wong and Looi, 2011), the authors presented two novel case studies of Mobile Assisted Language Learning (MALL) that emphasize learner-created content. In learning English prepositions and Chinese idioms, respectively, the primary school students used the mobile devices assigned to them on a one-to-one basis to take photos in real-life contexts so as to construct sentences with the newly acquired prepositions or idioms. Subsequently, the learners were voraciously engaged in classroom or online discussion of their semantic constructions, thereby enhancing their understanding of the proper usage of the prepositions or idioms. This work shows the potential of transforming language learning into an authentic seamless learning experience.

In (Che et al., 2009), the authors investigated the response of English majors to a mobile learning platform (NCCU-MLP) developed at National Chengchi University (NCCU) in which they were involved as participants. The goal of the NCCU-MLP is to improve the students' English ability as well as to update the teachers' understanding of how to use the technology. The purpose of this research was to investigate the responses of students to a mobile learning environment. The research involved 18 participants in a 
pilot study and 37 participants in a follow-up study who participated in a group activity involving mobile learning activities. The findings indicate a positive response from the participants regarding the content and procedures involved in the activity.

In Ros I Sole et al. (2010), the authors investigated whether a context-sensitive and social-oriented approach to MALL can be applied to the language learning context and how it is manifested. In order to carry out this investigation, the authors drew on literature on the development of identity in second language learning and the use of ethnographic approaches to data collection and interpretation. They reported on two case studies, involving learners of Icelandic and Serbian/Croatian, conducted over two years at a UK university. The paper concludes that the use of mobile technology enables language learners to use these devices as 'a prosthesis of the self' which allowed them to explore the perception of their L2 selves in a variety of day-to-day scenarios.

However, after a thorough investigation in the related scientific literature, we came up with the conclusion that there was no implementation of mobile assisted language learning system that combines student modeling and collaborative learning. Hence, we implemented a prototype system, which incorporates intelligence in its modeling component, offering the possibility of cooperation between students who reap the benefits of distant education.

\section{General Overview of The System and Methodologies Used}

In this section, we will describe how the collaboration is conducted and which method is used for the collaborative learning. Furthermore, we will present the purpose of the incorporation of student models and how they work. Finally, we will describe the error diagnosis component, the error categorization and how error diagnosis is involved in the language learning process, along with the students' problems emerging in it.

\subsection{Collaborative Learning}

One of the basic assets of our resulting e-learning system is the collaboration among students in the learning process. In order to efficiently carry out the collaborative learning, this module not only supports asynchronous text messaging, discussion and a message board, but also provides a mobile blog feature, which enables an easier process of answering students' questions. In order to increase the possibility of mutual understanding and optimized interaction, we use learning tools which are adequately related both to the new curriculum to be acquired and to the previous knowledge of the students. In this way, students may collaborate with their peers, discuss complex problems from various perspectives, evaluate information or co-use knowledge to solve exercises. In particular, we designed a framework to generate interdependencies among students, namely the need for information interchange during task performing, work splitting into several roles and the need for explicit knowledge sharing, as described above. These interdependencies are the key feature for effective collaborative language learning. 
The student should work in two aspects:

1. Study the theoretical part of the curriculum, concerning the grammatical elements of the foreign language taught. In this way, the student builds his knowledge state. Moreover, s/he can lean on the existing educational material or can cooperate with his/her peers.

2. Be evaluated by an intelligent assessment system without any help or hints by his/ her colleagues.

In our system, we have used the most common method of collaborative learning, which is Group Discussion and according to (Iowa State University, 2009) it is one of the most effective forms for collaborative learning. Group Discussion is a general unstructured discussion of an issue or topic by the group. Individual members are free to contribute or not contribute. It is also the form that requires the most skill to use successfully. Through mobiles, every student is actively involved in the discussion and the discussion topic (multiple language learning) is of equal interest to all group members. The misconceptions of students (as precisely described below) while trying to answer an exercise on their own or a question on the theory are the reason why they want to discuss and collaborate with their peers. Students are given clear directions about how they are supposed to work together and thus everyone participates and contributes to the discussion to the extent that they are able to do it. As illustrated in Fig. 1, when a student encounters a problem, s/he has the possibility of posing it towards his/her peers with the use of his/ her mobile phone. Every student should try to find a solution for the stated problem and propose it to his/her colleagues. After having worked on the problem individually, they can collaborate in order to search for understanding, meaning or solutions and to create an artifact of their learning through the system's support of joint problem solving. This activity renders the students capable of proposing new ideas. In this step, learners engage in a common question answering task where each individual depends on and is account-

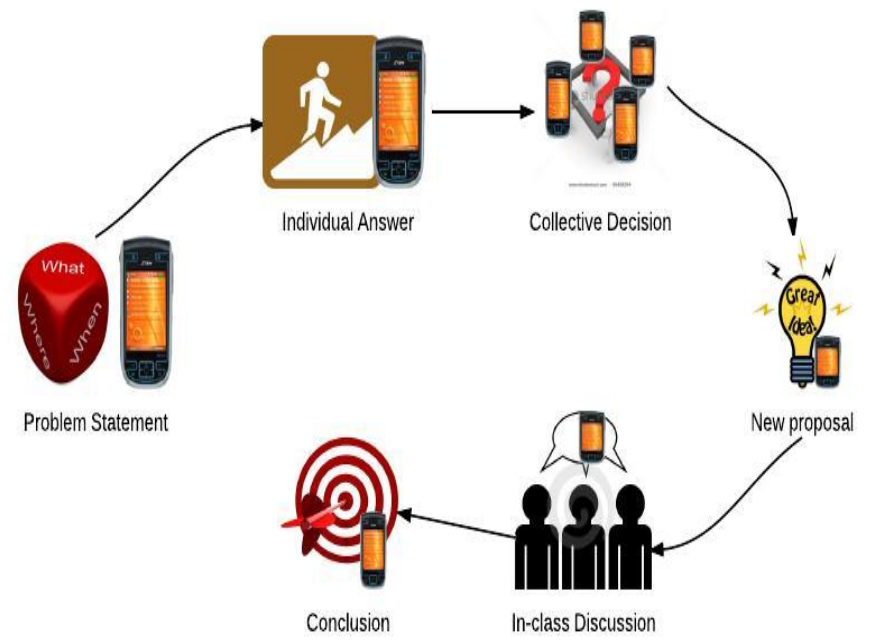

Fig. 1. Collaborative process for problem solving. 
able to each other through computer discussion. Finally, the joint intellectual effort by students, supported by the collaborative model, ameliorates the educational process by creating new horizons in the problem solving procedure.

\subsection{Problems Emerging from Language Learning in Respect of the Collaborative Process for Problem Solving}

Collaborative Learning is a framework that can be adapted to any tutoring system to generate dialogue between communities, improved understanding of the specific problem situation, increased rapport, respect, and trust among participants, clearly articulated system-based concerns about the problem situation and tangible improvements in the problem situation. Research shows that educational experiences that are active, social, contextual, engaging, and student-owned lead to deeper learning. The benefits of collaborative learning include:

- Development of higher-level thinking, oral communication, self-management, and leadership skills.

- Promotion of student-student interaction.

- Increase in student retention, self-esteem, and responsibility.

- Exposure to and an increase in understanding of diverse perspectives.

- Preparation for real life social and employment situations.

Learning a foreign language is an attractive task; thus, many students spend their entire life trying to achieve native-like fluency. They spend much time studying vocabulary, phrases, pronunciation or structure. However, despite their efforts, they still are confronted with problems in language learning, which are intended to be resolved by the collaboration framework presented in this paper. The collaboration is succeeded by exploiting crucial information which derives from the student models (which are described below). The system takes into account the knowledge level of each student, his/ her level of expertise on each language and the level of activeness on collaboration and contribution. In this way, a student who is very good at the use of articles and pronouns can collaborate with a student who is very good at verbs. Furthermore, a student who is very good at one language taught by our system (e.g. English) can collaborate with another student who is not good at this exact language (e.g. English), but s/he is good at the other language taught by our system (e.g. French). Each student is signed by the system with a star mark indicating at what field (e.g. pronouns, vocabulary etc) s/he is good. Therefore in case of collaboration, a student can ask for help either from any other student (without checking his/her star mark) or from a student who is good at the specific field according to his/her mark. Thereby, both students may reap the benefits of such collaboration and acquire new knowledge through cooperation. At this point, it is important to notice that the collaboration is conducted among members of "balanced" levels in terms of their strengths and weaknesses that correspond to the educational process of multiple language learning. In this way, our main effort was to provide students with the possibility of collaboration through mobiles phones so that no student would distinguish positively or negatively among other students. 


\subsection{Student Modeling and Diagnosis of Misconceptions}

Student models in intelligent tutoring systems represent student competencies and learning achievements (Woolf, 2010). Modeling may involve techniques to represent the knowledge skills of the student, namely his/her cognitive level in language learning along with his/her affective characteristics and emotional state. Although students' evaluation is conducted by exercise answering processes, their learning style, attitudes, and emotions are less easily determined and need to be inferred from long-term observations. Student models may be used for estimation by identifying changes in the student profiles, created by the aforementioned component. Student models generally represent inferences about users (specifically their level of knowledge, misconceptions, goals, plans, preferences, and beliefs), relevant characteristics of users (stereotypes) and users' records, particularly past interactions with the system. A student model observes student behavior and creates a qualitative representation of his/her cognitive knowledge (Virvou and Troussas, 2011). This model partially accounts for student performance, namely time on task and observed errors, and reasons about adjusting feedback to the student. One long-term goal of the field of education is to support learning for students with a range of abilities, disabilities, interests, backgrounds, and other characteristics (Shute et al., 2007). The student modeling component manages the explicit assumptions about a student in respect to his/her interaction with the tutor and offers instruction tailored to students' preferred learning style which increases their interest in learning and enhances learning, in part, because tutors can support weak students' knowledge and develops strong students' strengths (Woolf, 2010).

The student modeling component of our system has been based on the buggy approach. Namely, if a student gives an erroneous answer, then our system tries to perform misconception diagnosis be generating the faulty procedures of solution. If one of them is found to be match the student's answer then our system gives the user the appropriate kind of advice, with the support of the advice generator mechanism, and records the type of error identified in the student's personal record, so that it can maintain the history of his/her progress. This record constitutes the individual long term student model.

Misconception diagnosis in the student's domain of knowledge reveals intelligence by recognizing misconceptions and trying to associate them with one of the following five categories of errors:

1. Misconceptions in the use of articles and pronouns.

For example, the user may have used "the" instead of "an" or "you" instead of "he".

2. Misconceptions in spelling.

A spelling mistake results from letter missing, letter redundancy or interchange of two neighboring letters.

3. Misconceptions in the use of verbs.

Such mistakes occur when the user has typed another grammatical person in the use of verbs than the correct one, for example s/he may have typed "You has" instead of "You have". 
4. Unanswered questions.

The learner may have no idea about what the correct answer is and therefore s/he leaves the question unanswered. That means that $\mathrm{s} /$ he has lack in theory.

5. Confusion between multiple language learning / Language Transfer.

The resulting system is a multilingual learning system, which means that a student can learn two foreign languages at the same time. However, there is the possibility of student's getting confused, concerning the proper use of an article or verb when learning two languages at the same time.

In order to successfully recognize one or more of the aforementioned categories of errors, our system incorporates two algorithmic approaches (Fig. 2). The first one uses the approximate string matching technique and tries to find string similarities by matching a student's given "exact" wrong answer with the systems correct stored answer. If string matching occurs in a high percentage the system decides whether the mistake lies between categories 1-4. Correspondingly, using the second algorithm, the system also tries to find meaning similarities between the given and the correct answer by translating these two answers to the system's available supported languages. As an example, the student may have used "We have" instead of "Nous avons", which is the French equivalent.

When a student answers a question in the exercises section (as shown in Fig. 3), the system is responsible for deciding which the right answer is by corresponding the student's given answer to the right answer that is stored in the bug library (misconceptions database) of the system. Fig. 3 illustrates a categorization to a student's specific errors. The student can be evaluated and check where s/he is wrong and what type of mistake s/ he has made. In this way, the interconnection between the student modeling component (and its error diagnosis mechanism) and the problem solving activity is revealed. The different colors indicate different type of errors (Fig. 3):

- The red color in the field shows misconceptions in the use of articles and/or pronouns.

- The green color shows a misconception in the use of verbs.

- The yellow color shows a misconception in spelling.

- The blue color shows a misconception because of confusion between the French language, while the purple means confusion with the English language.

- Finally, the grey color shows an unanswered question.

Another aspect of the student modeling component of our system is the detection of the students' learning styles. The Felder-Silverman Learning Style Model (FSLSM) (Felder and Silverman, 1988) is the most appropriate learning style model for comput-

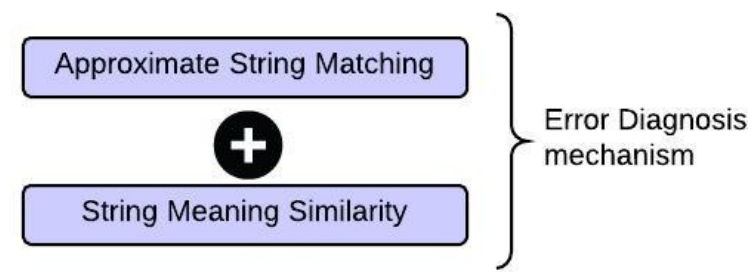

Fig. 2. Algorithmic approaches for the error diagnosis mechanism. 


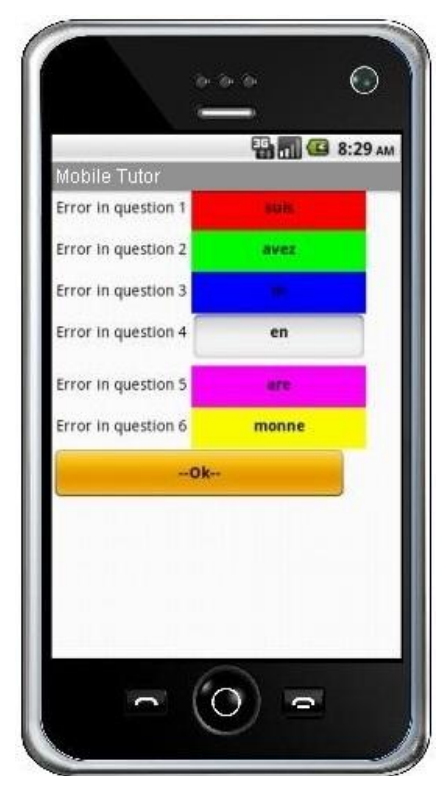

Fig. 3. Interconnection between student modeling and problem solving activities.

erized learning environment, as stated in (Graf et al., 2008) and therefore the authors of this paper have used the FSLSM in this research. The FSLSM explores three issues: (a) the aspects of learning style that is significant in engineering education, (b) the learning styles most preferred by students and the teaching styles most favored by educators, and (c) strategies that will reach students whose learning styles are not addressed by regular engineering education methods (Felder and Silverman, 1988).

FSLSM defines four learning style dimensions. The following is a brief summary of each of the dimensions:

1. Sensing and Intuitive Learners (Felder and Silverman, 1988): People tend to perceive the world. Sensing involves observing and gathering data through the senses; intuition involves indirect perception by way of the unconscious. Although learners will use both of these faculties, most will prefer using one to the other.

2. Visual and Verbal Learners (Felder and Silverman, 1988): Visual and auditory learning both have to do with learning processes that perceive information, and kinesthetic learning has to do with both perception such as taste, touch, and smell, and information processing such as moving, relating, or doing something active.

3. Active and Reflective Learners (Felder and Silverman, 1988): Active experimentation involves doing something with information in the external world, such as discussing it, explaining it, or testing it in some way. Reflective observation involves examining and manipulating the information introspectively. Active Learners do not learn much from lectures because they require them to receive information passively. They work and learn better in situations that allow for group work and hands on experimentation. Reflective Learners require situations that provide opportunity to think about the information being presented. They work well alone 
or in a one-on-one situation with another person and when given the opportunity to devise theories.

4. Sequential and Global Learners (Felder and Silverman, 1988): Sequential learners are comfortable with mastering material presented in a logically ordered progression, learning it as the educator presents it. They follow linear reasoning processes when solving problems, and can work with material even when they only have a partial or superficial understanding of it. They may be strong in convergent thinking and analysis, and learn best when educators present material in a steady progression of complexity and difficulty. Global learners tend to learn in bits and pieces: they may feel lost for days or weeks, unable to solve simple problems or show the most rudimentary understanding, until suddenly they "get it" - the light bulb flashes and the entire puzzle finally comes together. And as a result, they may understand the material well enough to apply it to problems that leave most of the sequential learners baffled. Global learners may have difficulty working with material that they only have a partial or superficial understanding of. They tend to make intuitive leaps and then have difficulty explaining how they came up with solutions. They tend to do better at divergent thinking and synthesis and have the ability to move directly to more complex and difficult material.

\section{Experimental Results and Discussion}

Human instructors and students are the cornerstone of an educational software. If these users, to whom an educational system is targeted, are not satisfied by the educational software, then they will not include this software into the learning process. Hence, evaluation of this kind of software is an important phase, because it helps the developer improve the effectiveness of the software. Also, the modeling of instructors and students constitutes the key of the educational process. Hence, in the scientific literature there have been presented evaluation methods which are completely focused on educational software.

One such evaluation framework outlines three dimensions to evaluate (Jones et al., 1999):

1. Context: The context determines the reason why the educational software is adopted in the first place, namely why it is developed and which is its primary goal.

2. Interactions: Users' interactions with the software reveal information about the users' learning processes.

3. Attitudes and Outcomes: This stage examines information from a variety of sources, such as pre and post achievement tests, interviews and questionnaires with students and tutors.

The underlying rationale of our mobile learning application concerns the offer of more convenience with respect to place, time, and kind of device to its users, therefore the context of the evaluation required an emphasis on the mobile aspect given that smartphones provide opportunities within professional education, curriculum education, and learning. 
For this reason, the context of the evaluation required an emphasis on learning through mobile phones. Finally, the "outcomes" stage involved pre and post-achievement tests to students and instructors before and after the use of the application.

To this end, in the evaluation of our mobile application both instructors and students took place and it was conducted in two different phases. At the first phase, only the instructors took place at the evaluation. At the second phase, the evaluation of the application was conducted and both instructors and students took place. The instructors of the second phase were exactly the same with the ones of the first phase, so that they could have a complete experience with our language learning application. At both phases, 5 instructors participated in the evaluation. All of them are foreign language teachers and were asked to use our mobile learning application, namely to check in detail the tutoring of multiple languages. All of the instructors who participated in the experiment were familiar with the use of mobile phones.

When questioned, all the instructors affirmed that our mobile language learning application was friendly to the users and that the mobile facilities were either useful or very useful for educational purposes. More specifically, four of them stated that they found the application very useful, while one of them stated that the application is useful. Concerning the question "How useful do you see the collaborative learning to students?", the instructors stated that they were all very satisfied from this feature.

The second phase was based on the framework presented in (Jones et al., 1999) and involved in total 40 users, both undergraduate and graduate. Mobile applications tend to be more convenient and flexible to use, as students spend much time in the use of mobile phones. Furthermore, the mobile devices can assure educational quality, given that they are increasingly used for learning purposes. However, there may be users who have not a flair for educational software in general or who have a flair for using mobile phones and are eager to use them for such purposes. Thus, one crucial aspect of the evaluation was to examine whether users were indeed helped by the mobile environment.

A second significant aspect was to find out whether users have gained educational benefits from the learning application and for this reason users were asked to use it. After using the application, the users were asked about their experience. $80 \%$ of the users declared that the whole educational software application is useful or very useful. An even greater percentage $(85 \%)$ found satisfactory the possibility of collaborative learning. Fig. 4 illustrates pie-charts, representing these results (users' answers).

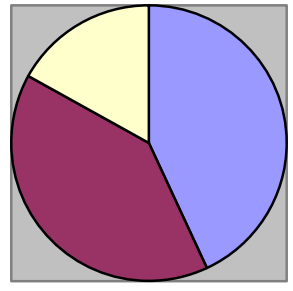

Learning application

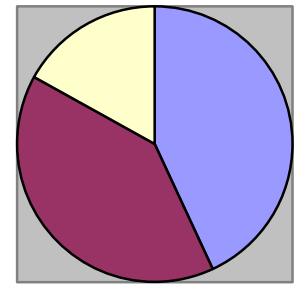

\begin{tabular}{l}
$\square$ Very Useful \\
$\square$ Useful \\
$\square$ Not Useful \\
\hline
\end{tabular}

Collaborative learning

Fig. 4. Usefulness of learning application (left pie-chart) and collaborative learning (right pie-chart). 


\section{Conclusion and Future Work}

In this paper, we have described a mobile-assisted language learning system which presents advances in pedagogical models in conjunction with inherent collaborative learning. Mobile technologies render our system ubiquitous, pervasive with enhanced capabilities for rich social interactions. Language learning can benefit from the cooperation between students who can learn everywhere with the support of wireless technologies. Moreover, language learning can further benefit from mobility, which provides chances for learners to personalize their collaborative educational process, to enhance their social interactions, to learn more autonomously and to collaborate with their peers at anytime and anywhere. Intelligence in collaboration can be proved by the exploitation of crucial information provided by the student models. Moreover, intelligence of the system can additionally be shown by the incorporation of the misconception diagnosis tool and of the advice generator mechanism of the mobile learning system.

However, collaborative learning, while beneficial within the complex and controversial educational process, is not a solution for every difficulty appeared in learning. It is a framework that can involve people in meaningful learning and discussion about challenging situations. It involves learning, understanding and development of improvements in the education. Collaborative learning does not foster the development of "mentality" of students. Rather, collaborative learning encourages students to make progress on improving the situation as they work together when learning the theory, answering questions or solving problems.

For this reason, it is in our future plans to further evaluate our system in order to examine the degree of usefulness of the mobile-supported collaborative system for language learning. Furthermore, we are going to evaluate the usefulness of the user modeling, including the error diagnosis and advice generator components in our system's collaborative language learning environment.

\section{References}

Caballe, S., Xhada, F., Baroli, L. (2010). Using mobile devices to support online collaborative learning. Mobile Information Systems, 6, 27-47.

Chang, C.K., Hsu, C.K. (2011). A mobile-assisted synchronously collaborative translation-annotation system for English as a foreign language (EFL) reading comprehension. Computer Assisted Language Learning, 24(2), 155-180.

Che, P.C., Lin, H.Y., Jang, H.C., Lien, Y.N., Tsai, T.C. (2009). A study of English mobile learning applications at National Chengchi University. International Journal of Distance Education Technologies, 7(4), 38-60.

Chen, W. (2002). Web services-what do they mean to Web-based education?. In: Proceedings of the International Conference on Computers in Education (ICCE'02). New Zealand.

Dillenbourg, P., Fischer, F. (2007). Basics of computer-supported collaborative learning. Zeitschrift fur Berufs und Wirtschaftspadagogik, 21, 111-130.

Felder, R.M., Silverman, L.K. (1988). Learning and teaching styles in engineering education. Engineering Education, 78, 674-681.

Graf, S., Lin, T., Kinshuk (2008). The relationship between learning styles and cognitive traits-getting additional information for improving student modeling. Computers in Human Behavior, 24, 122-137.

Jones, A., Scanlon, E., Tosunoglu, C., Morris, E., Ross, S., Butcher, P., Greenberg, J. (1999). Contexts for evaluating educational software. Interacting with Computers, 11(5), 499-516. 
Ros I Sole, C., Calic, J., Neijmann, D. (2010). A social and self-reflective approach to MALL. ReCALL, 22(1), 39-52.

Sandberg, J., Maris, M., De Geus, K. (2011). Mobile English learning: An evidence-based study with fifth graders. Computers and Education, 57(1), 1334-1347.

Shute, V.J., Zapata, D., Kuntz, D., Levy, R., Baker, B., Uther, M., Uther, J., Athanasopoulos, P., Singh, P., Akahane-Yamada, R. (2007). Mobile adaptive CALL (MAC). A lightweight speech-based intervention for mobile language learners. In: International Speech Communication Association - 8th Annual Conference of the International Speech Communication Association. 2, 1445-1448.

Iowa State University. (2009). SI Showcase: The Basic Collaborative Learning Techniques: Supplemental Instruction. Iowa State University. (Accessed on April 3, 2012).

http://www.dso.iastate.edu/asc/supplemental/SIShowcaseCollaborative.

Virvou, M., Troussas, C. (2011). Web-based student modeling for learning multiple languages. In: International Conference on Information Society (i-Society). 423-428.

Virvou, M., Alepis, E., Troussas, C. (2011). MMALL: multilingual mobile-assisted language learning. In: Proceedings of the First International Symposium on Business Modeling and Software Design. 129-135.

Virvou, M., Troussas, C. (2011). Personalized teaching of multiple languages through the web. International Journal for e-Learning Security (IJeLS), 1(1/2), 52-59.

Wong, L.H., Looi, C.K. (2010). Vocabulary learning by mobile-assisted authentic content creation and social meaning-making: two case studies. Journal of Computer Assisted Learning, 26(5), 421-433.

Woolf, B.P. (2010). Student modeling. Studies in Computational Intelligence, 308, 267-279.

C. Troussas is currently a Ph.D. Candidate in the Department of Informatics at the University of Piraeus in Greece. He received a M.Sc. degree in "Advanced Computing and Informatics Systems" (2010) and a B.Sc. degree in Informatics (2008) from the same Department. He has published over 30 articles in international conferences, books and journals. His current research interests are in the areas of user modelling, social networking services, artificial intelligence in education, mobile learning and adaptive systems.

M. Virvou is a Full Professor at the Department of Informatics, University of Piraeus in Greece. She received a Ph.D. Degree in Computer Science and Artificial Intelligence from the University of Sussex, UK (1993), a M.Sc. degree in Computer Science from the University College London, UK (1987) and a B.Sc. degree in Mathematics from the University of Athens, Greece (1986). She is Head of the Department of Informatics, University of Piraeus (Greece), Director of the Software Engineering Laboratory and also Director of postgraduate studies in the same Department. She has published over 300 articles in international conferences, books and journals. Her research interests are in the areas of user modelling, human-computer interaction, knowledge-based software engineering, artificial intelligence in education, adaptive systems and affective computing.

E. Alepis is a Lecturer at the Department of Informatics, University of Piraeus in Greece. He received a Ph.D. Degree in Informatics (2009) and a B.Sc. degree in Informatics (2002) from the same Department. He has published over 100 articles in international conferences, books and journals. His research interests are in the areas of mobile learning, mobile software, user modelling, artificial intelligence in education, adaptive systems and affective computing. 


\title{
Bendradarbiavimu grịstas mokymasis: grupès sąveika intelektualioje mobiliosiomis technologijomis paremtoje kalbų mokymosi sistemoje
}

\author{
Christos TROUSSAS, Maria VIRVOU, Efthimios ALEPIS
}

Straipsnyje pristatomas metodas, kurio centre yra mokinys. Metodas pritaikytas efektyviam kalbų besimokančių studentų bendradarbiavimui naudojant mobiliuosius telefonus ir intelektualią mokymo valdymo sistemą. Šiam tikslui buvo sukurtas intelektualus mobiliosios programos prototipas, apimantis modeliavimo ir diagnostinius komponentus. Vienas pagrindinių šio tyrimų tikslų - studento modelių, nagrinejjančių klaidingą informaciją, sudarymas. Jie yra pagrindas studentu bendradarbiavimui, diskusijoms ir rasti atsakymus ị besimokant iškylančius klausimus ir išspręsti problemas. Straipsnyje taip pat pristatomas mobilaus vadovavimo modelis, grịstas studentų bendradarbiavimu. Bendradarbiaujančios studentų grupès buvo kuriamos atsižvelgiant ị vartotojų modelius. Sukurtas prototipas buvo įvertintas ir gauti rezultatai patvirtino bendradarbiavimu grịsto mokymosi naudą. 